\title{
PENAMBAHAN KANGKUNG REBUS DAN AIR REBUSANNYA PADA MEDIA KULTUR INFUSORIA TERHADAP INDEKS KERAGAMNNYA
}

\section{Addition of boiled water spinach and water spinach boiled water on infusoria culture media on the diversity index}

\author{
Lilik Purwati $^{1}$, Syaeful Anwar ${ }^{2 *}$, Sumantriyadi $^{2}$, Indah Anggraini Yusanti ${ }^{3}$
}

1) Program Studi Ilmu Perikanan Fakultas Perikanan dan Kelautan Universitas PGRI Palembang

2) Program Studi Budidaya Ikan Fakultas Perikanan dan Kelautan Universitas PGRI Palembang

3) Program Studi Ilmu Perikanan Fakultas Perikanan dan Kelautan Universitas PGRI Palembang

*Corresponding author: syaeful.anwar81@gmail.com

\begin{abstract}
ABSTRAK
Infusoria berperan penting dalam rantai makanan. Infusoria memiliki ukuran tubuh yang kecil dan lembut, sehingga sesuai untuk larva ikan pada tahap awal pemberian pakan. Kangkung yang direbus beserta air rebusannya dapat digunakan sebagai media budidaya infusoria. Penelitian ini menggunakan metode Rancangan Acak Lengkap, perlakuan pertama media kultur infusoria dengan menambahkan gandum sebagai kontrol, kedua dengan menambahkan kangkung rebus, ketiga menggunakan air rebusan kangkung, dan ke empat menggunakan kangkung rebus dan air rebusan kangkung untuk melihat indeks pertumbuhan infusoria. Hasil penelitian menunjukkan indeks keanekaragaman populasi infusoria pada masing-masing media perlakua rendah, yaitu pada P0 dengan nilai 0.1, P1 dengan nilai 0.4 dan P2 dengan nilai 0.2 serta P3 dengan nilai 0.1. Sedangkan Fase-fase pertumbuhan infusoria yang diperoleh dalam penelitian ini terdapat ada 4 fase yaitu fase lag, fase eksponensial, fase stasioner, dan fase kematian.
\end{abstract}

Kata kunci : Infusoria, kangkung, rebus, pertumbuhan

\section{ABSTRACT}

Infusoria have an important role in the food chain. Infusoria has a small and soft body size, making it suitable for fish larvae in the early stages of feeding. Boiled of water spinach and the boiled water can be used as a medium for infusoria cultivation. This study used a completely randomized design method, the first treatment was infusoria culture media by adding wheat as a control, the second by adding boiled water spinach, the third using boiled water spinach, and the fourth using boiled water spinach and water spinach boiled water to see the growth index of infusoria. The results showed that the diversity index of the infusoria population in each treatment medium was low, namely at P0 with a value of 0.1, P1 with a value of 0.4 and $P 2$ with a value of 0.2 and P3 with a value of 0.1. Meanwhile, the infusoria growth phases obtained in this study contained 4 phases, namely the lag phase, the exponential phase, the stationary phase, and the death phase.

Keyword: Infusoria, water spinach, boiled, growth

\section{PENDAHULUAN}

Plankton merupakan sekelompok biota akuatik baik berupa tumbuhan maupun hewan yang hidup melayang maupun terapung secara pasif di permukaan perairan, dan pergerakan serta penyebarannya dipengaruhi oleh gerakan arus walaupun sangat lemah (Odum, 1998 
dalam Yuliana dkk., 2012; Sachlan, 1982 dalam Febrianto, 2020; Romimoharto, 2009 dalam Yusanti, 2018). Keragaman jenis plankton merupakan suatu penggambaran secara matematik yang dapat melukiskan struktur kehidupan dan dapat mempermudah menganalisis informasi-informasi tentang jenis dan jumlah plankton (Rahmatulloh dkk., 2016). Indeks keanekaragaman akan menggambarkan tingkat kemantapan atau stabilitas komunitas plankton (Sagala, 2012).

Infusoria merupakan mikroorganisme dan termasuk plankton yang tergolong kelompok ciliata dan flagellata. Ciliata ialah mikroba yang mempunyai sejumlah cilia atau bulu getar yang menjulur dari permukaannya. Flagellata ialah mikroba yang bergerak dengan menggunakan flagel atau bulu cambuk. Infusoria dari Kelompok cilliata antara lain yaitu Paramecium, Colpoda, Vorticella, dan Cycloposthium. Infusoria dari kelompok flagellata antara lain yaitu Euglena, Volvox, Brachiomonas, Goniaum, Chlamydomonas, Pandarina, dan Dinobryon (Sastrodinoto, 1980).

Infusoria berperan penting dalam rantai makanan. Infusoria memiliki ukuran tubuh yang kecil dan lembut, sehingga sesuai untuk larva ikan pada tahap awal pemberian pakan (Mukai dkk., 2016). Kandungan protein pada salah satu kelompok infusoria yaitu euglena mencapai 39-61\% (Nur, 2014), yang memenuhi standar SNI protein yang dibutuhkan oleh ikan. Menurut Sambode dkk. (2013), juga menyatakan Infusoria mempunyai kandungan gizi yang lengkap dan mudah dicerna dalam usus benih ikan. Ukuran tubuhnya yang relatif kecil sangat sesuai dengan bukaan mulut larva ikan. Sifatnya yang selalu bergerak aktif akan merangsang larva ikan untuk memangsanya jika menggunakan infusoria sebagai pakan alami maka akan dibutuhkan dengan jumlah yang banyak.
Salah satu cara termudah untuk mendapatkan pakan alami yaitu dengan cara mengkultur atau budidaya (Koniyo, 2011). Pada penelitian yang dilakukan oleh Dwirastina (2013), menggunakan media sayuran kangkung, bayam, dan mentimun, menunjukkan bahwa media kangkung berpengaruh sangat optimal terhadap pertumbuhan populasi infusoria. Kangkung air atau rawa memiliki bahasa latin Ipomoea memiliki kandungan gizi yang cukup tinggi dan mengandung vitamin A, $B$ dan vitamin $C$ serta bahan-bahan mineral terutama zat besi yang berguna bagi pertumbuhan badan dan kesehatan (Adrian, 2012). Pengukusan pada kangkung bertujuan untuk proses pemanasan guna untuk menonaktifkan enzim yang akan mengubah warna, cita rasa, maupun nilai gizi yang dilakukan pada suhu air lebih dari $66{ }^{\circ} \mathrm{C}$, tetapi kurang dari $82{ }^{\circ} \mathrm{C}$ (Adrian, 2012).

Kangkung yang digunakan pada penelitian Dwirastina, (2013) adalah kangkung yang telah direbus dan dibuang airnya. Galuh dkk., (2012), menggunakan air dari rendaman atau rebusan jerami. Selanjutnya Nugroho dkk., (2013), menggunakan media alang-alang beserta airnya menunjukkan hasil yang baik untuk pertumbuhan organisme.

Berdasarkan pernyataan $\mathrm{di}$ atas diduga bahwa, air rebusan dan juga kangkung beserta air rebusan dapat digunakan sebagai media budidaya infusoria. Oleh sebab itu perlu dilakukan penelitian untu mengetahui indeks keragaman infusoria serta mengtahui fasefase pertumbuhan kultur infusoria pada media kangkung yang berbeda.

\section{METODOLOGI}

\section{Waktu dan tempat}

Penelitian dilaksanakan selama 10 hari di Workshop Perikanan Universitas PGRI Palembang dan di Laboraturium Balai Riset Perikanan Perairan Umum dan Penyuluhan Perikanan Palembang. 


\section{Desain penelitian}

Penelitian ini menggunakan metode Rancangan Acak Lengkap (RAL). Rancangan Acak Lengkap digunakan apabila rancangan tersebut bersifat homogen. Dikatakan homogen apabila alat dan bahan yang digunakan sama atau seragam. Penelitian ini terdapat 12 percobaan dengan 3 (tiga) kali perlakuan dan 3 (tiga) kali ulangan, ditambah 1 (satu) perlakuan kontrol dengan 3 (tiga) kali ulangan.

Perlakuan $\mathrm{P}_{0}$ adalah media kultur infusoria berupa gandum sebanyak 1 (satu sendok) dan air sebanyak 5 liter. $\mathrm{P}_{1}$ adalah media kultur infusoria berupa kangkung rebus sebanyak 500 gr ditambah dengan air 5 liter. $\mathrm{P}_{2}$ adalah media kultur infusoria berupa air rebusan kangkung sebanyak 5 liter. $\mathrm{P}_{3}$ adalah media kultur infusoria berupa kangkung beserta air rebusannya sebanyak 5 liter.

\section{Preparasi Bahan dan Biota Uji}

Biota uji yang digunakan adalah infusoria yang berasal dari pembiakan yang dilakukan sebelum penelitian. Pembiakan yang dilakukan dengan bibit yang di ambil dari alam dan dibiakkan dengan media gandum. Bibit infusoria yang ditebar untuk setiap perlakuan sebanyak $10 \mathrm{ml}$ pada masing-masing perlakuan. Bahan uji yang digunakan yaitu berupa kangkung air yang didapatkan dari alam. Sebelum bahan uji digunakan dicuci terlebih dahulu, dipotong-potong, dan ditimbang sebanyak $500 \mathrm{~g}$ terlebih dahulu. Kangkung yang sudah ditimbang direbus sampai pada suhu $80^{\circ} \mathrm{C}$ yang dipertahankan selama 15 menit. Setelah kangkung direbus dibiarkan dingin dan dipisahkan dari airnya, dan juga ada yang dibiarkan tercampur dengan airnya.

\section{Prosedur Penelitian}

Persiapan Media Kultur

Pada proses penelitian ini hal pertama kali yang harus dilakukan yaitu persiapan media kultur infusoria berupa kangkung dan bibit infusoria. Bibit infusoria yang akan digunakan untuk penelitian dibiakkan terlebih dahulu dengan menggunakan kangkung yang sudah direbus dan dipisahkan dari airnya. Bibit infusoria yang digunakan untuk pembiakkan di ambil dari alam. Setelah dilakukan pembiakkan maka barulah menyiapkan media yang akan digunakan. Hasil biakkan yang digunakan yaitu pada fase stasioner sekitar berada pada hari ke 34.

Kangkung yang sudah disiapkan dicuci dan dipotong-potong menggunakan pisau. Potongan kangkung ditimbang sebanyak $3 \mathrm{~kg}$ dan dibagi menjadi enam yaitu masing-masing 500 gr. Kemudian dilakukan 6 (enam) kali perebusan, untuk setiap perebusan kangkung direbus dengan menggunakan air 5 (lima) liter pada suhu mencapai $80^{\circ} \mathrm{C}$ selama 15 menit (Adrian, 2012). Setelah semua selesai direbus maka dicampur semua hasil rebusan agar homogen. Setelah itu dibiarkan dingin terlebih dahulu barulah dipisahkan antara air dan kangkung tersebut. Kemudian dibagi untuk masing-masing perlakuan.

\section{Persiapan wadah}

Wadah yang akan digunakan berupa toples besar dengan volume 10 liter. Toples yang akan digunakan sebelumnya dibersihkan terlebih dahulu (Dwirastina dan Husnah., 2014). Setelah itu masingmasing media untuk setiap perlakuan dimasukkan ke dalam akuarium. Untuk P0 yaitu dimasukkan gandum sebanyak 1 (satu) sendok dan ditambah air sebanyak 5 liter. P1 dimasukkan kangkung rebus sebanyak 500 gr dan ditambahkan air sebanyak 5 liter. P2 dimasukkan air rebusan kangkung sebanyak 5 liter. P3 dimasukkan kangkung beserta air rebusan 5 liter. Kemudian diberi aerator pada masingmasing akuarium untuk suplai oksigen.

\section{Pengamatan dan Pengambilan Sampel}

Pengambilan sampel dilakukan setiap hari dikarenakan biasanya organisme yang akan diamati akan membelah atau 
berkembangbiak setiap 24 jam (Sambode dkk. 2012). Adapun langkah-langkah untuk mengambil sampel yang akan digunakan untuk pengamatan menurut Rahmatulloh dkk. (2016), dengan cara masing-masing perlakuan diambil sampel dengan menggunakan pipet tetes, sebanyak $10 \mathrm{ml}$, dan dimasukkan ke dalam masing-masing botol sampel dan dikomposit. Setelah sampel diambil diberi lugol untuk memberikan warna pada organisme guna mempermudah pengamatan. Pengamatan menggunakan SR (sedweight rafter). Selajutnya membersihkan SR (sedweight rafter) dan dikeringkan menggunakan kertas tisu diteteskan air sampel pada parit yang melintang dengan menggunakan pipet hingga penuh. Jangan sampai terbentuk gelembung, kemudian pasang gelas penutup untuk SR (sedweight rafter) dan dilakukan pengamatan dibawah mikroskop dengan pembesaran 100 atau 400 kali dan dicari bidang kotak-kotak yang terdapat mikroorganismenya. Untuk membantu mengingat dalam perhitungan digunakan hand counter. Setelah didapat hasil dari penghitungan kemudian dilakukan perhitungan kepadatan infusoria.

\section{Parameter yang Diamati}

Parameter yang diamati yaitu kepadatan populasi infusoria, fase-fase pertumbuhan infusoria, indeks keragaman infusoria dan kualitas air. Adapun kualitas air yang diamati antara lain suhu, $\mathrm{pH}, \mathrm{DO}$, dan amoniak.

\section{Jenis-jenis Infusoria}

Jenis-jenis infusoria ini dapat diketahui dengan cara diamati menggunakan mikroskop. Untuk mengetahui jenis-jenis infusoria apa saja yang terdapat dalam penelitian yaitu menggunakan panduan buku identifikasi rujukan Sachlan (1982).

\section{Fase-Fase Pertumbuhan Infusoria}

Fase-fase pertumbuhan infosuria dapat diketahui dengan mengetahui pertumbuhan populasi infusoria. Dengan diketahui populasi pertumbuhan infusoria dari hari kehari maka akan diketahui fasefase pertumbuhan, seperti fase lag, fase eksponensial, fase stasioner, dan fase kematian.

\section{Indeks Keanekaragaman}

Untuk mengetahui indeks keragaman maka diperlukan rumus indeks keanekaragaman Sagala, 2012.

$$
\mathbf{H}^{\prime}=-\sum \mathbf{P i} \text { In Pi }
$$

Keterangan :

$\mathrm{H}^{\prime}=$ indeks keanekaragaman

$\mathrm{Pi}=\mathrm{ni} / \mathrm{N}$

ni $=$ nilai individu satu jenis

$\mathrm{N}=$ jumlah total individu

\section{Kualitas Air}

Kualitas air yang diamati untuk suhu dan pH dilakukan setiap hari. Pengamatan dilakukan selama penelitian berlangsung yaitu pada pagi, siang dan sore hari (Dwirastina, 2013). Sedangkan untuk pengamatan DO dan ammonia dilakukan 2 (dua) kali selama penelitian yaitu pada awal penelitian dan akhir penelitian.

\section{HASIL DAN PEMBAHASAN Jenis-Jenis Infusoria}

Hasil pengamatan pada penelitian pakan alami infusoria dengan menggunakan media kangkung dengan 4 (empat) perlakuan dan 3 (tiga) ulangan yang dilakukan pengamatan selama 10 hari dan bertempat di Workshop Perikanan Universitas PGRI Palembang didapatkan hasil bahwa ditemukan 4 (empat) spesies yaitu Paramecium sp, Euglena sp, Stentor sp, dan Volvox sp. Data selengkapnya dan morfologi masing-masing spesies infusoria tertera pada Tabel 
Tabel 1. Jumlah Jenis-Jenis Infusoria (Paramecium $\mathrm{sp}$, Euglena $\mathrm{sp}$, Stentor $\mathrm{sp}$, dan Volvox $\mathrm{sp}$ )

\begin{tabular}{llll}
\hline No & Spesies & Jumlah $($ sel/l) & Persentase \% \\
\hline 1 & Paramecium $\mathrm{sp}$ & $22.923,9$ & 98,35 \\
2 & Euglena $\mathrm{sp}$ & 229,6 & 0,99 \\
3 & Volvox $\mathrm{sp}$ & 119,17 & 0,51 \\
4 & Stentor $\mathrm{sp}$ & 3,54 & 0,15 \\
\hline
\end{tabular}

Infusoria yang ditemukan pada penelitian ini ada dua kelompok yaitu kelompok flagellata (Euglena sp dan Volvox sp) dan kelompok cilliata (Paramecium sp, Stentor sp). Jenis Infusoria yang banyak ditemukan atau mendominasi pada masing-masing perlakuan yaitu Paramecium sp yang mencapai pada kelimpahan 2292,39 sel/1 dengan persentase $98,35 \%$. sedangkan spesies yang sedikit ditemukan yaitu spesies Stentor sp yang mencapai kelimpahan 3,54 dengan persentase $0,15 \%$. Kelimpahan tertinggi diikuti oleh Euglena sp dengan persentase $0,99 \%$ dan Volvox $\mathrm{sp}$ dengan persentase $0,51 \%$.

Hasil pengamatan pada masingmasing diketahui bahwa spesies Paramecium sp yang mendominasi dan pertumbuhannnya sangat pesat. Hal ini disebabkan oleh laju pertumbuhan Paramecium sp lebih tinggi dibanding infusoria spesies lainnya. Selain itu juga waktu generasi Paramecium sp juga lebih cepat dibandingkan dengan yang lain. Pada penelitian ini tidak dilakukan perhitungan waktu generasi tetapi pada penelitian sebelumnya yang dilakukan oleh Dwirastina (2013) menyatakan bahwa Paramecium sp mempunyai waktu generasi 10.5 jam sedangkan yang lainnya seperti Stentor sp membutuhkan waktu generasi selama 32 jam. Selain itu juga menurut Suriawiria (1985) dalam suatu populasi akan timbul kompetisi antara sesama organisme. Hal tersebut terjadi dimana yang kuat yang akan tetap tumbuh dan berkembang dan bagi yang lemah akan mati atau musnah.
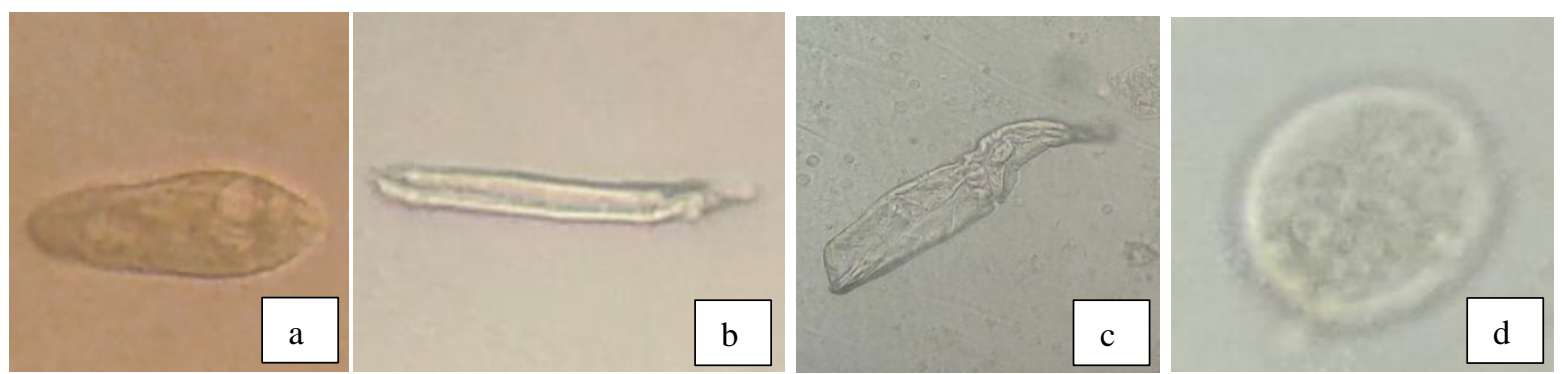

Gambar 1. (a) Stentor sp (b) Paramecium sp (c) Volvox sp (d) Euglena sp

Tubuh Paramecium sp terdapat sejumlah kanal (lubang) yang mengelilingi vakuola kontraktil pada tubuhnya. Selain itu Paramecium sp memiliki dua vakuola masing-masing terletak di ujung tubuhnya (Ijong, 2015). Stentor sp tubuhnya berbentuk tanduk, dengan cincin silia menonjol disekitar anterior. Manfaat dari cincin tersebut adalah untuk menarik makanan dan untuk berenang dan Stentor sp juga memiliki vakuola kontraktil. Euglena memiliki tubuh yang menyerupai gelendong dan diselimuti oleh pelikel Euglena viridis. Ukuran tubuhnya $35-60$ mikron dimana ujung tubuhnya meruncing dengan satu bulu cambuk (Handayani dkk., 2014). Volvox yaitu koloni yang berbentuk bulat atau oval berongga didalam dan 
mungkin lebih besar dari kepala peniti. Berisi sekitar 500 sampai 50000 sel koloni. Sel- sel dalam koloni yang terkandung dalam dinding jelly.
INDEKS KERAGAMAN INFUSORIA

Rata-rata indeks keanekaragaman Populasi infusoria pada masing-masing perlakuan terjadi perbedaan. Data selengkapnya dapat dilihat pada Tabel 2.

Tabel 2. Rata-Rata Indeks Keanekaragaman Populasi Infusoria pada Masing-Masing Perlakuan

\begin{tabular}{lll}
\hline No & Perlakuan & Indeks Keanekaragaman \\
\hline 1 & P0 (gandum+air) & 0,1 (rendah) \\
2 & P1 (kangkung rebus) & 0,4 (rendah) \\
3 & P2 (air rebusan kangkung) & 0,2 (rendah) \\
4 & P3 (kangkung+air rebusan) & 0,1 (rendah) \\
\hline
\end{tabular}

Data statistik untuk indeks

pembiakan dapat dilihat pada Tabel 3 keanekaragaman populasi infusoria pada dibawah ini. masing-masing perlakuan selama

Tabel 3. Statistik Indeks Keanekaragaman Populasi Infusoria

\begin{tabular}{lllllll}
\hline SK & DB & JK & KT & Fhitung & Ftabel & \\
\cline { 5 - 7 } & & & & & $\mathbf{5 \%}$ & $\mathbf{1 \%}$ \\
Perlakuan & 3 & 0,115 & 0,038 & $5,755^{*}$ & 4,07 & 7,59 \\
Galat & 8 & 0,053 & 0,007 & & & \\
Total & 11 & 0,168 & & & & \\
\hline
\end{tabular}

Hasil uji statistik dari indeks keanekaragaman infusoria pada masingmasing perlakuan menunjukkan bahwa berbeda nyata, yaitu $\mathrm{F}$ hitung $>\mathrm{F}$ tabel pada taraf 5\% dan $\mathrm{F}$ hitung $<\mathrm{F}$ tabel pda taraf
10\%. Dengan demikian maka untuk mengetahui ketelitiannya dilakukan uji lanjut BNT. Data hasil uji lanjut BNT dapat dilihat pada Tabel 4.

Tabel 4 .Uji Lanjut BNT Indeks Keanekaragaman Infusoria

\begin{tabular}{llll}
\hline \multirow{2}{*}{ Perlakuan } & \multirow{2}{*}{ Rata-rata } & Notasi & \\
\cline { 3 - 4 } & & $\mathbf{5 \%}$ & $\mathbf{1 \%}$ \\
\hline P0 & 0,09 & $\mathrm{a}$ & $\mathrm{A}$ \\
P1 & 0,45 & $\mathrm{a}$ & $\mathrm{A}$ \\
P2 & 0,15 & $\mathrm{a}$ & $\mathrm{A}$ \\
P3 & 0,10 & $\mathrm{a}$ & $\mathrm{A}$ \\
\hline
\end{tabular}

Indeks keanekaragaman tertinggi terjadi pada P1 dengan nilai indeks keanekaragaman 0,4 . Untuk perlakuan $\mathrm{P} 0$ dan P3 memiliki indeks keanekaragaman terendah diantara empat perlakuan dan juga memiliki nilai yang sama yaitu 0,1 . Selanjutnya P2 memiliki indeks keanekaragaman yang lebih tinggi dari $\mathrm{P} 0$ dan P3 tetapi masih rendah dari P2 yaitu dengan nilai 0,2. Berdasarkan kriteria dalam rumus indeks keanekaragaman Simpson keanekaragaman pada masingmasing perlakuan dikategorikan dalam indeks keanekaragaman yang rendah (Rahmatulloh, 2016). Menurut Astirin dkk (2012) indeks keanekaragaman yang 
rendah mengindikasikan bahwa dalam ekosistem tersebut ada kecenderungan dominasi jenis. Indeks keanekaragaman yang cenderung rendah biasanya mengalami tekanan fisik dan kimia (Odum, 2004 dalam Wibowo, 2014).

Uji statistik indeks keanekaragaman populasi infusoria pada berbagai perlakuan menunjukkan hasil bahwa terjadi perbedaan pada masingmasing perlakuan. Dari tabel diatas maka diperoleh hasil bahwa $\mathrm{F}$ hitung $>\mathrm{F}$ tabel pada taraf 5\% dan $\mathrm{F}$ hitung $<\mathrm{F}$ tabel pda taraf $10 \%$. Maka pernyataan $\mathrm{H} 1$ diterima dan H0 ditolak.

Berdasarkan uji lanjut BNT didapatkan hasil bahwa perlakuan kontrol berpengaruh signifikan terhadap P1 tetapi tidak signifikan terhadap P2 dan P3. P1 signifikan terhadap P2 tetapi tidak signifikan terhadap P3, sedangkan P2 tidak signifikan terhadap P3. Berdasarkan hasil uji tersebut dapat disimpulkan bahwa P0 (gandum) signifikan terhadap P1 (ampas) dan P2 (air kangkung) = P3 (campuran). Untuk indeks keanekaragaman media yang sebaiknya digunakan ialah ampas kangkung, karena mempunyai indeks keragaman yang lebih maksimal dibandingkan dengan media lainnya.

Data statistik untuk indeks keanekaragaman pada masing-masing spesies infusoria selama pembiakan dapat dilihat pada Tabel 5.

Tabel 5. Rata-rata Indeks Keanekaragaman Pada Masing-Masing Perlakuan Berdasarkan Spesies

\begin{tabular}{lllll}
\hline \multirow{2}{*}{ Perlakuan } & Spesies & & & \\
\cline { 2 - 5 } & Paramecium $\mathbf{s p}$ & Euglena $\mathbf{s p}$ & Stentor $\mathbf{s p}$ & Volvox $\mathbf{s p}$ \\
\hline P0 & 0,01 & 0,03 & 0,02 & 0,00 \\
P1 & 0,03 & 0,25 & 0,00 & 0,04 \\
P2 & 0,02 & 0,03 & 0,01 & 0,07 \\
P3 & 0,01 & 0,04 & 0,01 & 0,11 \\
\hline
\end{tabular}

Indeks keanekaragaman infusoria pada masing-masing spesies juga mengalami perbedaan pada masing-masing perlakuan. Data selengkapnya dapat dilihat pada Tabel 5.

Tabel 5. Rata-rata Indeks Keanekaragaman Pada Masing-Masing Perlakuan Berdasarkan Spesies

\begin{tabular}{lllll}
\hline & Spesies & & & \\
\cline { 2 - 5 } Perlakuan & Paramecium sp & Euglena sp & Stentor sp & Volvox $\mathbf{s p}$ \\
\hline P0 & 0,01 & 0,03 & 0,02 & 0,00 \\
P1 & 0,03 & 0,25 & 0,00 & 0,04 \\
P2 & 0,02 & 0,03 & 0,01 & 0,07 \\
& & & & \\
P3 & 0,01 & 0,04 & 0,01 & 0,11 \\
\hline
\end{tabular}

Data statistik untuk indeks keanekaragaman pada masing-masing spesies infusoria selama pembiakan dapat dilihat pada Tabel 6. 
Tabel 6. Uji Statistik Indeks Keanekaragaman Paramecium sp, Euglena sp, Stentor sp, dan Volvox sp

\begin{tabular}{|c|c|c|c|c|c|c|}
\hline \multirow{2}{*}{ SK } & \multirow{2}{*}{ DB } & \multirow{2}{*}{ JK } & \multirow{2}{*}{ KT } & \multirow{2}{*}{ Fhitung } & \multicolumn{2}{|c|}{ Ftabel } \\
\hline & & & & & 0.05 & 0.01 \\
\hline \multicolumn{7}{|c|}{ a. Paramecium sp } \\
\hline Perlakuan & 3 & 0,00812 & 0,00271 & $36,87 * *$ & 4,07 & 7,59 \\
\hline Galat & 8 & 0,00010 & 0,00001 & & & \\
\hline Total & 11 & 0,00822 & & & & \\
\hline \multicolumn{7}{|c|}{ b. Euglena $\mathrm{sp}$} \\
\hline Perlakuan & 3 & 0,11 & 0,04 & $5,94 *$ & 4,07 & 7,59 \\
\hline Galat & 8 & 0,05 & 0,01 & & & \\
\hline Total & 11 & 0,15 & & & & \\
\hline \multicolumn{7}{|c|}{ c. Stentor sp } \\
\hline Perlakuan & 3 & 0,00056 & 0,00271 & $89,64 * *$ & 4,07 & 7,59 \\
\hline Galat & 8 & 0,00002 & 0,00001 & & & \\
\hline Total & 11 & 0,00058 & & & & \\
\hline \multicolumn{7}{|c|}{ d. Volvox sp } \\
\hline Perlakuan & 3 & 0,00050 & 0,00016 & $215,13 * *$ & 4,07 & 7,59 \\
\hline Galat & 8 & 0,00004 & 0,00005 & & & \\
\hline Total & 11 & 0,00054 & & & & \\
\hline
\end{tabular}

Hasil perhitungan indeks keanekaragaman tertinggi infusoria Euglena sp dengan nilai berkisar antara 0,03-0,25. Menurut Yusanti (2019), Euglena sp merupakan zooplankton yang mampu beradaptasi dengan kondisi lingkungan perairan. Infusoria yang paling rendah untuk nilai keanekaragaman yaitu Stentor sp dengan nilai berkisar antara $0,00-0,02$. Selanjutnya dengan nilai tertinggi kedua diikuti oleh Volvox sp yang memiliki nilai berkisar antara 0,00- 0,11. dan selanjutnya Paramecium sp dengan nilai berkisar antara 0,01-0,03. Menurut Hasti (2011) dalam Ramadhan (2020), paramecium memiliki tingkat reaksi yang sangat rendah dan tidak mempunyai sistem saraf. Genus Paramecium ini dapat bereaksi terhadap cahaya dan perubahan suhu.

Berdasarkan kriteria dalam rumus indeks keanekaragaman Simpson keanekaragaman pada masing-masing spesies dikategorikan dalam indeks keanekaragaman yang rendah (Rahmatulloh, 2016). Menurut Wilhm \& Dorris (1968) dalam Yuliana dkk (2012) nilai indeks keanekaragaman $\left(\mathrm{H}^{\prime}\right) \leq 1$ termasuk keanekaragaman rendah, dan nilai $1 \leq \mathrm{H}^{\prime} \leq 3,00$ keanekaragaman sedang. Apabila dalam suatu ekosistem

atau perairan terjadi dominasi spesies maka indeks keanekaragaman akan rendah (Wibowo, 2014).

Uji statistik indeks keanekaragaman infusoria pada keempat spesies dengan berbagai perlakuan menunjukkan hasil bahwa terjadi perbedaan yang sangat nyata pada masingmasing perlakuan. Dari tabel 18 diperoleh $\mathrm{F}$ hitung $>\mathrm{F}$ tabel pada taraf 5\% maupun $10 \%$. Tetapi pada tabel $16 \mathrm{~F}$ hitung $>\mathrm{F}$ tabel pada taraf 5\% dan $\mathrm{F}$ hitung $<\mathrm{F}$ tabel pad taraf $10 \%$. Maka dari hasil tersebut pernyataan yang diterima $\mathrm{H} 1$ dan $\mathrm{H} 0$ 
ditolak. Data statistik indeks keanekaragaman populasi infusoria dan masing-masing spesies dapat dilihat pada Lampiran 3.

\section{Kualitas Air}

Parameter kualitas air suhu, $\mathrm{pH}$ dan DO pada setiap perlakuan masih berada dalam kisaran toleransi. Secara ilmiah setiap organisme termasuk Infusoria mempunyai kemampuan untuk menyesuaikan diri terhadap perubahan yang terjadi di lingkungannya yang masih dalam tingkat toleransi (Hora, 1962 dalam Dwirastina, 2013). Hasil pengamatan kualitas air selama kegiatan penelitian ditampilkan pada Tabel 7 berikut.

Tabel 19. Data Pengukuran Kualitas Air

\begin{tabular}{|c|c|c|c|c|c|c|}
\hline $\begin{array}{l}\text { Paramete } \\
\mathbf{r}\end{array}$ & $\begin{array}{l}\text { Perlakuan } \\
\text { P0 }\end{array}$ & P1 & & $\mathbf{P 2}$ & P3 & Kisaran toleransi \\
\hline Suhu $\left({ }^{0} \mathrm{C}\right)$ & $26-27$ & $26-27$ & & $26-27$ & $26-27$ & $24-30$ \\
\hline $\mathrm{pH}$ & $6-7,5$ & $6-7,5$ & & $6-7,5$ & $6-7,5$ & $5-9$ \\
\hline $\mathrm{DO}(\mathrm{ppm})$ & $1,98-4,84$ & $\begin{array}{l}1,74 \\
4,74\end{array}$ & - & $1,83-4,76$ & $1,69-4,74$ & $1-4$ \\
\hline $\begin{array}{l}\text { Amoniak } \\
(\mathrm{mg} / \mathrm{l})\end{array}$ & $0,164-3,889$ & $\begin{array}{l}0,117- \\
3,888\end{array}$ & & $0,117-3,889$ & $1,118-3,889$ & $0,003-1,1731$ \\
\hline
\end{tabular}

Untuk kandungan amoniak dalam media termasuk tinggi yaitu berkisar antara 0,164 - 3,889 mg/l. Menurut Haris (2018); Haris (2019); Ramadhan (2020) menyatakan bahwa kandungan amoniak yang terlalu tinggi maka akan berdampak buruk bagi kehidupan organisme air. Amoniak juga merupakan salah satu parameter kualitas air yang mempengaruhi pertumbuhan dan juga kehidupan suatu organisme. Nilai optimum amoniak antara 0,003 -1,1731 mg/l. Untuk simpangan baku nilai amoniak untuk pertumbuhan organisme yaitu $0,2446 \quad(\mathrm{mg} / \mathrm{l})$ (Marsambuana dkk., 2011). Lebih lanjut

\section{KESIMPULAN}

Indeks keanekaragaman populasi infusoria pada masing-masing media perlakuan rendah, yaitu pada $\mathrm{P} 0$ dengan nilai $0.1, \mathrm{P} 1$ dengan nilai 0.4 dan $\mathrm{P} 2$ dengan nilai 0.2 serta P3 dengan nilai 0.1. Sedangkan Fase-fase pertumbuhan infusoria yang diperoleh dalam penelitian ini terdapat ada 4 fase yaitu fase lag, fase eksponensial, fase stasioner, dan fase kematian.

\section{DAFTAR PUSTAKA}

Adrian. 2012. Deskripsi Mikroskopis dan Kandungan Mineral Tanaman Kangkung Air. Skripsi. Fakultas Perikanan dan Ilmu Kelautan Institut Pertanian Bogor. Bogor.

Astirin, O.P., Setyawan, A. D dan Harini, M. 2012. Keragaman Plankton sebagai Indikator Kualitas Sungai di Kota Surakarta Plankton diversity as bioindicator of Surakarta rivers quality. Jurnal Biodiversitas 3(2): 236-241.

Dwirastina, M. 2013. Kepadatan Infusoria pada Pembiakan Secara Terkontrol dengan Berbagai Media. Skripsi. Fakultas Perikanan Universitas PGRI Palembang. Palembang.

Dwirastina, M dan Husnah. 2014. Inventarisasi Jenis-Jenis Infusoria dengan Media Kangkung Rawa. Prosiding Seminar Nasional Lahan Suboptimal.. Palembang, 26-27 September 2014. 
Febrianto, M.T., Yusanti, I.A., Anwar, S. 2020. Keanekaragaman Plankton Di Sungai Komering Desa Serdang Menang Kecamatan Sirah Pulau Padang Kabupaten OKI. Jurnal Sainmatika. Vol. 17(1). Hal 9-16

Galuh, A. D., Budijastuti, W dan Rachmadiarti, F. 2012. Resistensi Paramaecium caudatum terhadap Logam Tembaga $(\mathrm{Cu})$ dengan Pemberian Pakan Pseudomonas fluorescens pada Media Jerami. Jurnal Lentera Bio 1(2):105-110.

Handayani, T., Mulyanto, A dan Sopiah, N. 2014. Penyerapan Emisi $\mathrm{CO}_{2}$ oleh Mikroalga Euglena sp dengan Bioreaktor Kolam Kultur. Jurnal Ecoleb 8(1):1-152.

Haris, RBK, Yusanti, I.A. 2018. Studi Parameter Fisika Kimia Air untuk Keramba Jaring Apung Di Kecamatan Sirah Pulau Padang Kabupaten Ogan Komering Ilir Provinsi Sumatera Selatan. Jurnal Ilmu-ilmu Perikanan dan Budidaya Perairan. Vol.13 (2). Hal : 61-66.

Haris, RBK., Yusanti, I.A. 2019. Analisis Kesesuaian Perairan untuk Keramba Jaring Apung di Kecamatan Sirah Pulau Padang Kabupaten Ogan Komering Ilir Provinsi Sumatera Selatan. Jurnal Lahan Suboptimal. Vol. 8(1) hal: 20-30.

Ijong, F.G. 2015. Mikrobiologi Perikanan dan Kelautan. Rineka Cipta. Jakarta: $61 \mathrm{hlm}$.

Marsambuana, A.P dan Utojo. 2011. Hubungan Antara Kelimpahan Plankton dan Peubah Kualitas Air di Kawasan Pertambakkan Kabupaten Tangkep Provinsi Sulawesi Selatan. Prosiding Forum Inovasi Teknologi
Akuakultur. Sulawesi Selatan. Sulawesi Selatan.

Nugroho, T., Budijastuti, W dan Faizah, U. 2013. Pola Pertumbuhan Populasi Vorticella Globosa pada Media Kultur Air Rendaman Alang-alang, Bekatul, dan Gedebok Pisang dengan Berbagai Konsentrasi. Jurnal Lentera Bio 2(2):155-160.

Nur, M. M. A. 2014. Potensi Mikroalga sebagai Sumber Pangan Fungsional di Indonesia (overview). Jurnal Eksorgi. 11(2):1-66.

Rahmatulloh, Ali, M. A dan Karina,S. 2016. Keanekaragaman dan Dominansi Plankton di Estuari Kuala Rigaih Kecamatan Setia Bakti Kabupaten Aceh Jaya. Jurnal Ilmiah Mahasiswa Kelautan dan Perikanan Unsyiah 1(3):325-330.

Ramadhan, R., dan Yusanti, I.A. 2020. Studi Parameter Studi Kadar Nitrat Dan Fosfat Perairan Rawa Banjiran Desa Sedang Kecamatan Suak Tapeh Kabupaten Banyuasin. Jurnal Ilmuilmu Perikanan dan Budidaya Perairan. Vol 15(1) : 37-41. DOI: http://dx.doi.org/10.31851/jipbp.v15 i1.4407.

Ramadhan., Mutiara, D dan Yusanti, I.A. 2020. Keanekaragaman Jenis Pakan Pada Lambung Ikan Sepat Siam (Trichogaster pectoralis) Di Rawa Banjiran Desa Sedang Kecamatan Suak Tapeh Kabupaten Banyuasin. Jurnal Akuakultur Rawa Indonesia. Vol.8(2) : 164 - 175.

Sachlan, M. 1982. Planktonologi. Fakultas Peternakan dan Perikanan Universitas Diponegoro. Semarang.

Sagala, E. P. 2012. Indeks Keanekaragaman dan Indeks 
Saprobik Plankton dalam Menilai Kualitas Perairan Laut Bangka di Sekitar FSO Laksmiati PT. MEDCO $\mathrm{E} \& \mathrm{P}$ INDONESIA, Kabupaten Bangka Barat, Propinsi Bangka Belitung. Jurnal Maspari 4(1):23-32.

Sambode, D., Pangkey, H dan Lantu, S. 2013. Pertumbuhan Cladocera Jenis Chydoridae pada Media Kultur yang Berbeda. Jurnal Budidaya Perairan 1(2):1-7.

Sastrodinoto, S. 1980. Biologi Umum. Gramedia Pustaka Utama. Jakarta: $187 \mathrm{hlm}$.

Suriawiria, U. 1985. Mikrobiologi Air. Alumni Bandung : $36 \mathrm{hlm}$.

Wibowo, H. P. E., Purnomo,T dan Ambarwati,R. 2014. Kualitas Perairan Sungai Bengawan Solo di Wilayah Kabupaten Bojonegoro
Berdasarkan Indeks Keragaman Plankton. Jurnal Lentara Bio 3(3):209-215.

Yuliana., Adiwilaga, E.M., Haris, E dan Pratiwi, N.T.M. 2012. Hubungan Kelimpahan Antara Fitoplankton dan Parameter Fisisk Kimiawi di Perairan Teluk Jakarta. Jurnal Akuatika. 3(2):169-179.

Yusanti, I.A., Widayatsih, T., Ramadhan. 2018. Keanekaragaman Zooplankton di Rawa Banjiran Kecamatan Suak Tapeh Kabupaten Banyuasin. Jurnal Biota. Vol 1 (1). Hal : 7-11.

Yusanti, I.A. 2019. Kelimpahan Zooplankton Sebagai Indikator Kesuburan Perairan Di Rawa Banjiran Desa Sedang Kecamatan Suak Tapeh Kabupaten Banyuasin. Jurnal Sainmatika. Vol. 16 (1). Hal : 33-39. 